\title{
THE
}

\section{Disability Type, Financial Capability, and Risky Asset Holding}

Jing Jian Xiao

University of Rhode Island, jjxiao@uri.edu

Barbara O'Neill

Follow this and additional works at: https://digitalcommons.uri.edu/hdf_facpubs

\section{Citation/Publisher Attribution}

Xiao, J. J., \& O'Neill, B. (2021). Disability Type, Financial Capability, and Risky Asset Holding. Journal of Disability Policy Studies. https://doi.org/10.1177/1044207320981781

Available at: https://doi.org/10.1177/1044207320981781

This Article is brought to you for free and open access by the Human Development and Family Science at DigitalCommons@URI. It has been accepted for inclusion in Human Development and Family Science Faculty Publications by an authorized administrator of DigitalCommons@URI. For more information, please contact digitalcommons-group@uri.edu. 
DISABILITY TYPE AND RISKY ASSET HOLDING

Xiao, J. J., \& O'Neill, B. (2020). Disability type, financial capability, and risky asset holding. Journal of Disability Policy Studies. Forthcoming.

DISABILITY TYPE, FINANCIAL CAPABILITY, AND RISKY ASSET HOLDING

\author{
Jing Jian Xiao, Ph.D. (Contact author) \\ Professor \\ Department of Human Development and Family Studies \\ University of Rhode Island, Kingston, RI 02881, USA
}

Email: xiao@uri.edu; Phone: 401-874-2547

ORCID: 0000-0003-3252-5672

\author{
Barbara O'Neill, Ph.D. \\ Distinguished Professor \\ Rutgers Cooperative Extension \\ Cook Office Building Room 107 \\ 55 Dudley Road, New Brunswick, NJ 08901, USA \\ E-mail: boneill@njaes.rutgers.edu Phone: $\underline{\text { 848-932-9126 }}$
}

\title{
Acknowledgements
}

The authors of this paper would like to express their sincere appreciation to Michael Rousch and Nanette Goodman from the National Disability Institute for reviewing an initial draft of this paper and providing helpful feedback. Also we thank Gary Mottola at the FINRA Investor Education Foundation for providing helpful information regarding the dataset. 
DISABILITY TYPE AND RISKY ASSET HOLDING 
DISABILITY TYPE AND RISKY ASSET HOLDING

DISABILITY TYPE, FINANCIAL CAPABILITY, AND RISKY ASSET HOLDING

\author{
Abstract \\ Risky financial asset holding is considered an indicator of financial well-being since risky \\ asset holders are likely to accumulate more wealth than non-holders. Like the general population \\ in the U.S., many people with disabilities need long-term financial planning services. The \\ purpose of this study was to examine whether disability type and financial capability are \\ associated with risky asset holding of adults with disabilities. Using data from the 2015 National \\ Financial Capability Study, we found that adults with different types of disabilities have different \\ chances of holding risky assets. After controlling for financial capability, income, and other \\ variables in the logistical model, people who are deaf or have difficulties running errands are \\ more likely, while people with a work disability are less likely, than the mentally disabled to \\ hold risky financial assets. In addition, two financial capability variables, objective financial \\ knowledge and desirable financial behavior, are positively associated with risky asset holding \\ after controlling for other factors. Several disability, financial capability, and other factors \\ showed differences in risky asset holding when lower income and higher income subsamples \\ were examined. \\ Keywords: disability, financial capability, National Financial Capability Study, risky asset \\ holding
}


Adults with disabilities are an important population that needs financial services. More than 17 million Americans with disabilities receive financial benefits from the U.S. Social Security Administration (SSA) through the Supplemental Security Income (SSI) or the Social Security Disability Insurance (SSDI) programs, or both. Of this cohort, 3.5 million adults with disabilities are appointed a representative payee to manage their benefits because they have been determined not to be financially capable (Birkenmaier et al., 2017; SSA, 2015). Many adults with disabilities need financial planning services. Among the population with disabilities, for those with a family income of $\$ 75,000$ or higher, $44.5 \%$ or more hold non-retirement risky financial assets (Figure 1).

A relatively new government policy shift may further increase this demand. The Achieving a Better Life Experience (ABLE) Act, signed into law in December 2014, amended the tax code to encourage contributions to an ABLE account that allow investments to grow taxfree. Congress recognized that families raising a child with a significant disability and workingage adults with disabilities have additional costs associated with the disability (Goodman et al., 2017; Napach, 2016; Waddell, 2017). Helping adults with disabilities in financial planning will help enhance their financial capability and improve their financial well-being.

Research on the financial capability and well-being of the population with disabilities is emerging. In this study, financial capability is defined as the ability of applying financial knowledge and engaging in desirable financial behavior to achieve financial well-being (Xiao \& O’Neill, 2016). Scholars at the National Disability Institute conducted a comprehensive study by comparing financial capability and well-being indicators between working-age people with disabilities and the general population (Goodman et al., 2017). A few studies also examined the 
DISABILITY TYPE AND RISKY ASSET HOLDING

financial capability of adults with specific types of disabilities (Lazar et al., 2016; Kavaliunas et al., 2015). In this study, we examined whether disability type and financial capability are associated with risky asset holding of adults with disabilities.

Risky financial assets refer to financial assets with uncertain returns (except for government bonds that are not considered risky assets but may be risky when inflation risk is considered). Financial risk tolerance varies by consumer characteristics that result in different risk-taking behaviors (Grable, 2016). Holding risky assets is a basis for measuring financial sophistication (Calvet et al. 2009; Huston et al., 2012) and also considered an indicator of financial well-being where people holding risky assets are more likely to accumulate more wealth compared to those who do not (Campbell, 2016).

In the literature, financial capability and risky asset holding are positively associated (Liao et al., 2017). Due to the unique health and financial situations of adults with disabilities, this association may show different patterns than the general population. Also, adults with different types of disabilities may also have different health and financial circumstances, which may show differences in terms of the association between financial capability and risky asset holding. Compared to previous research, this study makes unique contributions to the literature by including disability type in the analyses and by examining the association between the financial capability and risky asset holding of adults with disabilities. The results will be informational for policy makers and financial service professionals who work with clients with disabilities.

\section{Financial Capability of Adults with Disabilities: Background}

Financial capability of adults with disabilities has its own unique features. Allmark and Machaczek (2015) argued, in a position paper, that financial capability should not be viewed as a 
DISABILITY TYPE AND RISKY ASSET HOLDING

personal quality in isolation from a person's socio-economic environment and that there are two distinct types of financial capability: in poverty and not in poverty. Palmer (2011) examined links of three definitions of poverty to disability (basic needs, capability, and economic resources) and concluded that, however it is defined, poverty is closely related to disability.

National data show that a large number of people with disabilities are financially fragile.

Researchers at the National Disability Institute examined the financial capability and well-being of adults with disabilities with data from the 2015 National Financial Capability Study (NFCS) and noted that people with disabilities face many barriers to financial stability including low/unstable incomes, inadequate health insurance, and susceptibility to health problems related to their disability, resulting in both lost income and medical expenses (Goodman et al., 2017). Compared to others, adults with disabilities are more than twice as likely to find it "very difficult" to cover expenses and pay bills (23\% vs. 9\%); twice as likely to have past due medical bills ( $38 \%$ vs. $18 \%$ ) and to forgo medical care (46\% vs $25 \%$ ); less likely to be employed (39\% vs. $69 \%$ ); less likely to have three months of emergency funds (30\% vs $46 \%$ ); and less likely to have a retirement account (40\% vs. 62\%) and non-retirement accounts (20\% vs. 31\%) (Goodman et al., 2017).

Research using samples of adults with specific types of disabilities shows those in the studies are financially fragile compared to other adults. Lazar et al. $(2015,2016)$ tested a tool to rate the financial capability of 118 persons who received SSDI payments, had recently been treated in acute care facilities for psychiatric disorders, and who did not have representative payees or conservators. Almost half (48\%) of the participants were found to be financially incapable for a variety of reasons (e.g., harmful spending on illicit drugs). In addition, as 
DISABILITY TYPE AND RISKY ASSET HOLDING

expected, financially incapable persons scored higher on a money mismanagement measure compared to capable ones.

Kavaliunas et al. (2015) studied relationships between earnings and Social Security compensation and disability from Multiple Sclerosis (MS). Not surprisingly, disease progression affected the finances of MS patients considerably. The average level of earnings was ten times lower when comparing MS patients with severe and mild disability. The employment-population ratio of working-age people with disabilities in the labor force is about one-third of that of people with no disability (The Arc, 2016; U.S. Bureau of Labor Statistics, 2018). Milfort et al. (2014) examined barriers to employment among 430 SSDI beneficiaries who received comprehensive vocational and mental health services but were not successful in returning to work. It is important to note, however, that adults in the above studies comprise a very small portion of adults with specific disabilities and are not representative of people with disabilities in general.

\section{Disability Type and Risky Asset Holding}

People with disabilities have unique investment opportunities. Even though persons with disabilities face means tests (i.e., an examination of income and/or assets to determine benefit program eligibility) for government programs that limit the income and/or resources of beneficiaries, income from investments is "unearned" and not counted for Social Security disability (Zacks, 2019). Thus, applicants for benefits can invest in stocks, earn dividends, and realize capital gains because personal resources such as cash and stocks do not affect eligibility (Zacks, 2019). ABLE (Achieving a Better Life Experience) investment accounts were implemented as vehicles which allow children and adults with disabilities to save money without jeopardizing federal benefits (Waddell, 2017). ABLE accounts are similar to state 529 college savings plans but more limited in their numbers and more flexible in terms of benefits (Napach, 
DISABILITY TYPE AND RISKY ASSET HOLDING

2016). In addition, employed people with disabilities and people with disabilities who are not working need to distinguished since employed individuals may have job related benefits but those not working do not have access to these benefits.

Previous research indicates that cognitive ability correlates with investing behavior. Christelis, Jappelli, and Padula (2010) studied the relationship between cognitive abilities and portfolio choices among a sample of European adults and found that propensity to invest in stocks is strongly associated with cognitive abilities for both direct stock purchases and indirect participation through mutual funds and retirement savings accounts. However, to our knowledge, no previous research examined disability type and risky asset holding of the disabled and no evidence suggested that people with mental disabilities are different from those with other types of disabilities in terms of investing behavior. Therefore, we propose the following hypothesis:

H1: There are no differences between adults with different types of disabilities in terms of risky asset holding.

\section{Financial Capability and Risky Asset Holding}

In the standard model of investing, holding risky assets is a desirable financial behavior (Cardak \& Wilkins, 2009). Holding risky assets implies that the holders have a higher level of risk tolerance and are likely to achieve a higher level wealth due to superior investment performance over extended periods of time (Campbell, 2016). Financial researchers examined factors associated with risky asset holding and identified background risk factors that are mainly socioeconomic characteristics of households (Cardak \& Wilkins, 2009). The health risk factor plays a similar role as background risk factors (Campbell, 2006), which has direct implications for the population with disabilities. 
DISABILITY TYPE AND RISKY ASSET HOLDING

Among factors affecting risky asset holding, financial capability is an important one.

Financial capability can be defined in a variety of ways (Huston, 2010; Lin et al., 2016; Johnson \& Sherraden, 2007; Lusardi \& Mitchell, 2014). In this study, we define financial capability as an individual's ability to apply appropriate financial knowledge and engage in desirable financial behavior for achieving financial well-being (Xiao \& O’Neill, 2016). Previous research showed that financial knowledge is positively associated with stock or risky asset holding (Chu et al., 2017; Liao et al., 2017; Van Rooij et al., 2011). Research also shows that people with high perceived financial knowledge coupled with high or low actual financial knowledge, or high actual financial knowledge coupled with high or low perceived knowledge, are more likely to buy stocks or hold IRAs than those who are low in both actual or perceived financial knowledge (Allgood \& Walstad, 2016).

Based on the above discussion, we propose the following hypothesis:

H2: Financial capability is positively associated with risky asset holding among adults with disabilities.

\section{Method}

\section{Data}

Data used in this study were from the 2015 U. S. National Financial Capability Study (NFCS), commissioned by the FINRA Investor Education Foundation and conducted by Applied Research and Consulting LLC, which included 27,564 American adults (roughly 500 per state and the District of Columbia). Descriptive statistics and other background information about this data set can be found in a report by its owner (Lin et al., 2016). The NFCS is a triennial survey, started in 2009 , that has been widely used and validated as a representative sample of the 
DISABILITY TYPE AND RISKY ASSET HOLDING

American population by researchers in economics, business, consumer science, and other social science fields.

In the 2015 survey, several new questions were asked about specific statuses of disabilities. In this study, adults with any disability were initially selected for the analyses. We consulted with staff of the National Disability Institute who conducted similar analyses (Goodman et al., 2017) about the data regarding the sample of people with disabilities and they reported that those who reported all "yes" answers for the six new disability status questions may not be serious answers, Thus, among 6,322 respondents who claimed having at least one type of disability, we removed those who checked "yes" for all six disability types, which resulted in a sample size of 6,151 . Further, we limited respondents to those aged 18 to 65 , which reduced the sample size to 4,920 .

\section{Variables}

Table 1 presents detailed information about variable specifications used in this study. Risky asset holding was measured by a binary variable indicating if holding non-retirement investments such as stocks, bonds, mutual funds and other equity, in which 1 refers to yes and 0 no. Based on previous research (Goodman et al., 2017). disability statuses were measured by seven binary variables: being disabled in hearing, seeing, concentrating, working or climbing stairs, dressing or bathing, doing errands, or work, where 1 refers to yes and 0 , no. Note that the first six disability questions were new to the 2015 NFCS and the work disability question was asked in the previous NFCS.

Following previous research (Xiao \& O’Neill, 2016), four financial capability variables included objective financial literacy, subjective financial literacy, desirable financial behavior, and perceived financial capability. Objective financial literacy is the quiz score of six financial 
DISABILITY TYPE AND RISKY ASSET HOLDING

knowledge questions ranging from 0 to 6 . Subjective financial literacy is a self-assessment of financial knowledge with a range of 1-7 (1=very low, 7=very high). Desirable financial behavior is a sum of five desirable financial behavior binary variables such as underspending, having an emergency fund, having a budget, setting up a long-term plan, and calculating retirement needs, which ranged from 0 to 5 . Perceived financial capability is a self-assessment of money management ability with a range of 1-7 (1=very low, 7=very high).

Following previous research (Cardak \& Wilkins, 2009), several demographic and financial variables associated with risky asset holding were also included in the analyses as control variables (see more details in Table 1). Following previous research (Cardak \& Wilkins, 2009), the age squared term is also included to identify the possible nonlinear effect of age.

\section{Data Analyses}

Descriptive statistical analyses were conducted with the whole sample. Descriptive statistical analyses of risky asset holding by disability type and financial capability were also conducted. To test the hypotheses, binary logistic regressions were used with the whole sample and with income subsamples, in which the dependent variable was risky asset holding and the independent variables were disability types, financial capability, and control variables. Additional analyses among two income subsamples were also conducted since factors associated with risky financial asset holding among lower and higher income people may be different.

\section{Results}

\section{Descriptive Statistics of the Sample}

Table 2 presents descriptive statistics of the total sample and subsamples by two income subsamples (under $\$ 75,000$ and $\$ 75,000$ and higher) and Table 3 presents descriptive statistics of 


\section{DISABILITY TYPE AND RISKY ASSET HOLDING}

risky asset holding by disability type and financial capability. For the whole sample of adults with disabilities, respondents who reported having mental and walking disabilities had the largest percentage, $46 \%$, followed by respondents who reported having difficulties in running errands (34\%) and those who reported having a work disability (24\%). Percentages of the sample for other disabilities were $18 \%$ who reported having serious difficulty in hearing, $15 \%$ having serious difficulty in seeing, and 15\% having serious difficulty in dressing or bathing.

Among the whole sample, 19\% reported holding non-retirement risky assets. Regarding financial capability variables, the mean score of objective financial knowledge was 2.76 out of 6 (46\%), subjective financial knowledge was 4.91 out of 7 (70\%), financial behavior was 2.37 out of $5(47 \%)$, and perceived financial capability was 5.38 out of 7 (77\%).

Table 1 also presents the sample's other characteristics. Among the sample, the average age was $44,43 \%$ were males, $42 \%$ were married, and $36 \%$ had financially dependent children. Percentages of three education groups were similar: $35 \%$ had high school or lower education, $32 \%$ had some college, and $33 \%$ had an associate degree or more education. About half (52\%) were credit constrained, where they had difficulty raising $\$ 2,000$ in an emergency, $35 \%$ had no credit card, and $36 \%$ owed credit card debt.

The respondents seemed risk neutral, with an average risk attitude score of 4.69 out of 10 . About half owned a home (48\%). The income distribution was that $42 \%$ had incomes under $\$ 25,000,27 \%$ had incomes of $\$ 25,000-\$ 50,000$, and $31 \%$ had incomes of $\$ 50,000$ or more. Among the whole sample, $22 \%$ had employer-sponsored defined contribution retirement plans, 19\% had non-employer provided retirement accounts, and 39\% were working.

Table 3 presents descriptive statistics of risky asset holding and financial capability variables by disability type. Among disability types, three disability types that had much higher 


\section{DISABILITY TYPE AND RISKY ASSET HOLDING}

than average holding rates were the deaf (35\%), blind (27\%), and dressing difficulty (24\%).

Three disability types had similar holding rates compared to the average rate: difficulty running errands (18\%), walking difficulty (18\%), and mental difficulty (17\%). The work disability group had the lowest risky asset holding rate, only $6 \%$.

For financial capability variables, among seven disability types, only three types were higher than the average score of objective financial knowledge: the deaf, blind, and walking difficulty group, while the other four types scored lower than the average. Four disability types had scores higher than the average of subjective financial knowledge: the deaf, blind, walking difficulty, and dressing difficulty group.

Regarding desirable financial behavior, only two types, the deaf and blind group, had the higher than average score. Finally, for perceived financial capability, only three disability types had a higher than average score: the deaf, walking difficulty, and work disability group. To summarize, it appears that two disability types, the deaf and walking difficulty group, had a higher level of financial capability compared to other disability types.

\section{Logistic Regression Results with the Whole Sample}

Table 4 Column 1 presents logistic regression results with the whole sample. Compared to the reference category, those with a mental disability, the deaf and those having difficulty running errands were more likely, while those with work disability were less likely to hold risky financial assets. Specifically, the deaf were $35.4 \%$ more likely, the running errand difficulty respondents were $45.4 \%$ more likely, and work disability respondents were $47.5 \%$ less likely to hold risky financial assets than the reference category, the mental disability group. Two financial capability variables, objective financial knowledge and desirable financial behavior, showed positive associations with risky asset holding. 


\section{DISABILITY TYPE AND RISKY ASSET HOLDING}

Several other variables showed associations with risky asset holding. Risk attitude was positively associated with risky asset holding. Age showed a U-pattern effect in terms of risky asset holding. Three variables showing credit constraints (no $\$ 2,000$, no credit card, and having credit card debt) were negatively associated with risky asset holding. Holding assets such as a home, employer sponsored, or non-employer sponsored retirement accounts, were positively associated with risky asset holding. For income groups, only those with income of $\$ 50,000$ or higher were more likely than the reference category, the group with income under $\$ 25,000$, to hold risky assets. The Cox \& Snell $\mathrm{R}^{2}$ and Neglkerke $\mathrm{R}^{2}$ are two measures of the explaining power of a model. The results suggest that independent variables in the model explained $29.6 \%$ and $47.7 \%$ of the variance of the dependent variable, respectively.

\section{Logistic Regression Results with Income Subsamples}

Figure 1 shows that if respondents have family income $\$ 75,000$ or more, $44.5 \%$ or more of them held risky financial assets. To examine if factors associated with risky asset holding are different between two income subgroups, similar multivariate logistic analyses were conducted, one for those with income under $\$ 75,000$ and the other for those with income of $\$ 75,000$ or higher. Table 4 column 2 and 3 present the results, among which, for the lower income subsample, the Cox \& Snell $\mathrm{R}^{2}$ and Neglkerke $\mathrm{R}^{2}$ are $21.1 \%$ and $38.9 \%$, respectively; and for the higher income subsample, the Cox $\&$ Snell $\mathrm{R}^{2}$ and Neglkerke $\mathrm{R}^{2}$ are $33.4 \%$ and $44.5 \%$, respectively.

In the lower income group, the pattern was the same as the whole sample, the deaf and running errand difficulty group were more likely while the work disability were less likely to hold risky asset, compared to the reference category, the mental difficulty group. In the higher income group, no difference was found between the mental difficulty group and any other 
DISABILITY TYPE AND RISKY ASSET HOLDING

disability types. The potential effects of financial capability variables were also different for the two groups. In the lower income group, both objective financial knowledge and desirable financial behavior showed positive associations with risky asset holding, while in the higher income group, objective financial knowledge did not show the association.

Several other variables showed the same associations in both subsamples such as risk attitude, having difficulty raising $\$ 2,000$ in an emergency, owning a home, and having nonemployer sponsored retirement accounts. Only in the lower income group, three variables (having associate or higher degrees, no credit card, and having 401k type retirement plans) showed associations with risky asset holding. Only in the higher income group, two variables (age and having credit card debt) showed associations with risky asset holding.

\section{Discussion}

This study has examined risky asset holding among adults with disabilities with a national sample. People with different disability types exhibit some differences in terms of risky asset holding status. Multivariate analysis results show that people with a work disability are less likely, while people who are deaf or have serious difficulty running errands are more likely, than the reference category, the mentally disabled, to hold risky assets after controlling for financial capability and other factors. But there are no differences between mental disability and three other disability types (blind, dressing, and walking disability). This finding provides partial support for Hypothesis 1 (There is no difference between adults with physical and mental disabilities in terms of risky asset holdings).

Two of four financial capability variables show positive associations with risky asset holding after controlling for other factors: objective financial knowledge and desirable financial behavior. These findings are partially consistent with Hypothesis 2 (Financial capability is 
DISABILITY TYPE AND RISKY ASSET HOLDING

positively associated with risky asset holding among adults with disabilities) and previous

research showing that financial knowledge contributes to risky asset holding (Chu et al., 2017;

Liao et al., 2017; Van Rooij et al., 2011).

Results from two income subsamples show differences in factors associated with risky asset holding. In the lower income sample, the patterns are similar to those of the whole sample. Respondents with a work disability are less likely and those who have hearing disabilities and difficulty running errands are more likely than the mentally disabled (the reference group) to hold risky assets. In the higher income sample, no differences in disability types are found.

Findings also show unique variables only in the lower income or the higher income group. In the lower income group only, three variables (having an associate or higher degree, no credit card, and having 401(k) type retirement plans) show differences in terms of risky asset holding; while only in the higher income group, three variables (age, age squared, and having credit card debt) show differences.

\section{Limitations}

The variable of risky asset holding is only a binary variable that has limited information for furthering understanding of the investment behavior of adults with disabilities. A more desirable measure should include dollar values of all types of risky assets that can be used to form portfolios to better show the financial positions of people with disabilities. Another limitation is that self-reported financial and medical information may have measurement errors. More desirable measures are to link relevant administrative data with survey data to more accurately describe these people's behavior and wellbeing. Finally, differences of risky holding patterns among workers with disabilities, non-workers with disabilities, and people without disabilities could also be explored. Previous research shows some interesting behavioral patterns 
DISABILITY TYPE AND RISKY ASSET HOLDING

between people with disabilities and people without disabilities in many aspects of financial knowledge, behavior, and wellbeing (Goodman et al., 2017). These issues should be addressed in future research.

\section{Implications}

People with disabilities account for $12.7 \%$ of the U.S. civilian noninstitutionalized population (U.S. Census, 2017) and are an important constituency for policy makers and financial service practitioners. They face barriers to financial stability such as a low or unstable income, thinner margin of health, and the extra costs associated with living with a disability such as medical care, medication, and medical equipment (Goodman et al., 2017). Not all disabilities are the same, however, with some having a greater impact on earning ability and the availability of investment capital. In addition, some disabilities begin early in life while others begin later after individuals have established themselves financially.

This study has explored the association between different types of disabilities and risky asset holding and whether various measures of financial capability are positively associated with risky asset holding among adults with disabilities. Below are implications for policymakers and professionals who assist people with disabilities:

Earning Ability is a Key Variable. Fewer than one in three working age adults with a disability are employed, compared to $75 \%$ of those without a disability (Morris, 2018). This study found that people with a work disability are less likely to hold risky assets, which is a practice linked to financial wellbeing and wealth-building. Clearly, income is a key pre-requisite for building wealth. Financial service practitioners with clients with disabilities (or their family members) can assist them with referrals to career counseling and job training programs and employers that hire people with disabilities. Options for telework that involve fewer barriers 
DISABILITY TYPE AND RISKY ASSET HOLDING

(e.g., commuting, travel, and building access) could also be explored. In addition, referrals for legal assistance may be warranted. because employers who do not hire people with disabilities may be violating the Americans with Disabilities Act (ADA). Unless people with disabilities improve their ability to work and earn a higher income, they are unlikely to have available capital to invest in any type of asset. With appropriate supports and public policies, fewer disabilities should preclude the ability to work.

Some Disabilities Present More Challenges Than Others. People with disabilities are a diverse group with a wide range of types and severity of disabilities (Morris, 2018). This study finds differences in risky asset holding between persons with physical and mental disabilities. Specifically, respondents with hearing disabilities and difficulty running errands are more likely and those with work disabilities are less likely than the mentally disabled to hold risky assets. Mental disabilities may not preclude work entirely like a severe physical injury would and may be easier to work around. They may also occur later in life after someone has already built some wealth. Clearly, clients with disabilities are not a homogeneous group of clients and require personally tailored financial products and services from financial advisors to create a better future for themselves and their families. Some may be able to manage investment accounts while others require a representative payee to manage their finances. Financial practitioners can assist individuals and families with a wide range of disability severity levels.

Leverage Opportunities Under the ABLE Act. Wealth-building by persons with disabilities who receive government benefits has traditionally been limited by asset tests. In 2014, Congress passed the ABLE Act, which created an option for people with disabilities to save for the future while preserving their eligibility for public benefits. Eligibility requirements to open an ABLE account are age of onset of disability before age 26 and proof of significant 
DISABILITY TYPE AND RISKY ASSET HOLDING

functional limitations (Morris, 2018). Before persons with disabilities can even consider risky assets, they need encouragement to save and a place to hold their savings. Financial service practitioners can help them set up ABLE accounts as a first step. This is especially true for persons with disabilities having lower incomes who were less likely to hold risky assets. In addition, findings from this study clearly show that some people with disabilities do invest. These results can be used to advocate for additional public policies (e.g., investment tax credits and targeted educational programs) that support asset building by vulnerable populations.

Educate Clients About Investment Risks. Risk tolerance is an important factor in investment behavior (Grable, 2016). When financial advisors work with clients holding risky asset investments, they need to educate them about the characteristics of those assets and also evaluate clients' ability to sustain their finances when facing market shocks, especially negative shocks. Advisors should also be aware of certain consumer characteristics associated with different levels of financial risk tolerance. Clients who are male, younger, and single are more likely to take financial risk than their female, older, and married counterparts. Advisors may use different strategies to help these clients accordingly. 


\section{References}

Allgood, S., \& Walstad, W. B. (2016). The effects of perceived and actual financial literacy on financial behaviors. Economic inquiry, 54(1), 675-697.

Allmark, P., \& Machaczek, K. (2015). Financial capability, health and disability. BMC Public Health, 15(1), 1-5.

Birkenmaier, J., Aranda, M., Appelbaum, P. S., \& Norman, M. A. (2017). For their financial benefit: determination of financial capability for adult beneficiaries of social security disability. Social Work, 62(3), 271-273.

Calvet, L. E., Campbell, J. Y., \& Sodini, P. (2009). Measuring the financial sophistication of households. American Economic Review, 99(2), 393-98.

Campbell, J.Y., (2006). Household finance. Journal of Finance, 61, 1553-1604.

Campbell, J. (2016). Restoring rational choice: The challenge of consumer financial regulation. American Economic Review: Papers \& Proceedings, 106(5): 1-30.

Cardak, B. A., \& Wilkins, R. (2009). The determinants of household risky asset holdings: Australian evidence on background risk and other factors. Journal of Banking \& Finance, $33(5), 850-860$.

Christelis, D., Jappelli, T., \& Padula, M. (2010). Cognitive abilities and portfolio choice. European Economic Review, 54(1), 18-38.

Chu, Z., Wang, Z., Xiao, J. J., \& Zhang, W. (2017). Financial literacy, portfolio choice, and financial well-being. Social Indicators Research, 132(2), 799-820.

Goodman, N., O’Day, B., \& Morris, M. (2017). Financial capability of adults with disabilities. Washington, DC: National Disability Institute. 
DISABILITY TYPE AND RISKY ASSET HOLDING

https://www.realeconomicimpact.org/assets/site_18/files/other_documents/finra\%20repor t/ndi-finrareport-accessible.pdf

Grable, J. E. (2016). Financial risk tolerance. In J. J. Xiao (ed.). Handbook of consumer finance research (pp. 19-32). New York: Springer.

Huston, S. J. (2010). Measuring financial literacy. Journal of Consumer Affairs, 44(2), 296-316.

Huston, S. J., Finke, M. S., \& Smith, H. (2012). A financial sophistication proxy for the Survey of Consumer Finances. Applied Economics Letters, 19(13), 1275-1278.

Johnson, E., \& Sherraden, M. S. (2007). From financial literacy to financial capability among youth. Journal of Sociology \& Social Welfare, 34(3), 119-146.

Kavaliunas, A., Wiberg, M., Tinghög, P., Glaser, A., Gyllensten, H., \& Alexanderson, K., et al. (2015). Earnings and financial compensation from social security systems correlate strongly with disability for multiple sclerosis patients. Plos One, 10(12), e0145435.

Lazar, C. M., Black, A. C., Mcmahon, T. J., O'Shea, K., \& Rosen, M. I. (2015). Determining financial capability of SSI/SSDI beneficiaries with psychiatric disabilities: A case series. Psychiatric Services, 66(3), 279-284.

Lazar, C. M., Black, A. C., Mcmahon, T. J., Rosenheck, R. A., Ries, R., \& Ames, D., et al. (2016). All-data approach to assessing financial capability in people with psychiatric disabilities. Psychological Assess, 28(4), 362-371.

Liao, L., Xiao, J. J., Zhang, W., \& Zhou, C. (2017). Financial literacy and risky asset holdings: Evidence from China. Accounting and Finance, 57, 1383-1415.

Lin, J. T. Bumcrot, C., Ulicny, T., Lusardi, A., Mottola, G., Kieffer, C., \& Walsh, G. (2016). Financial capability in the United States 2016. Washington, DC: FINRA Investor Education Foundation. 
DISABILITY TYPE AND RISKY ASSET HOLDING

Lusardi, A., \& Mitchell, O. S. (2014). The economic importance of financial literacy: Theory and evidence. Journal of Economic Literature, 52(1), 5-44.

Milfort, R., Bond, G.R., McGurk, S.R., \& Drake, R.E. (2015). Barriers to employment among Social Security disability insurance beneficiaries in the mental health treatment study. Psychiatric Services, 66(12), 1350-1352. https://ps.psychiatryonline.org/doi/abs/10.1176/appi.ps.201400502.

Morris, B. (2018). Advancing economic self-sufficiency: Challenges and opportunities for people with disabilities. Washington, DC: National Disability Institute. http://choosetosave.org/asec/Michael\%20Morris.pdf.

Napach, B. (2016). ABLE Accounts: What advisors need to know. Think Advisor. https://www.thinkadvisor.com/2016/08/05/able-accounts-what-advisors-need-to-know.

Palmer, B. (2011). Disability and poverty: A conceptual review. Journal of Disability Policy Studies, 21(4), 210-218. http://journals.sagepub.com/doi/pdf/10.1177/1044207310389333.

Social Security Administration. (2015). Capability determination: Overview. https://secure.ssa.gov/poms.nsf/lnx/0200502010

The Arc (2016). Employment issues for people with disabilities. Public Policy and Legal Advocacy. https://www.thearc.org/what-we-do/public-policy/policy-issues/employment.

U.S. Bureau of Labor Statistics. (2018). Table A-6. Employment status of the civilian population by sex, age, and disability status, not seasonally adjusted. https://www.bls.gov/news.release/empsit.t06.htm

U.S. Census. (2017). Disability characteristics: 2017 American Community Survey 1-year estimates. 
DISABILITY TYPE AND RISKY ASSET HOLDING

https://factfinder.census.gov/faces/tableservices/jsf/pages/productview.xhtml?pid=ACS_1

5_1YR_S1810\&prodType=table

U.S. Census (n.d.). Disability characteristics: 2015 American Community Survey 1-year estimates.

https://factfinder.census.gov/faces/tableservices/jsf/pages/productview.xhtml?pid=ACS_1

5_1YR_S1810\&prodType=table

Van Rooij, M., Lusardi, A., \& Alessie, R. (2011). Financial literacy and stock market participation. Journal of Financial Economics, 101(2), 449-472.

Waddell, M. (2017). ABLE alliance launches investment accounts for disabled, blind. Think Advisor. https://www.thinkadvisor.com/2017/02/14/able-alliance-launches-investmentaccounts-for-dis/?slreturn=20180222194836.

Xiao, J. J., \& O’Neill, B. (2016). Consumer financial education and financial capability. International Journal of Consumer Studies, 40(6), 712-721.

Zacks Investment Research (2019). Can a person on Social Security invest in stocks? https://finance.zacks.com/can-person-social-security-invest-stocks-2686.html. 
DISABILITY TYPE AND RISKY ASSET HOLDING

Table 1: Variable Specifications

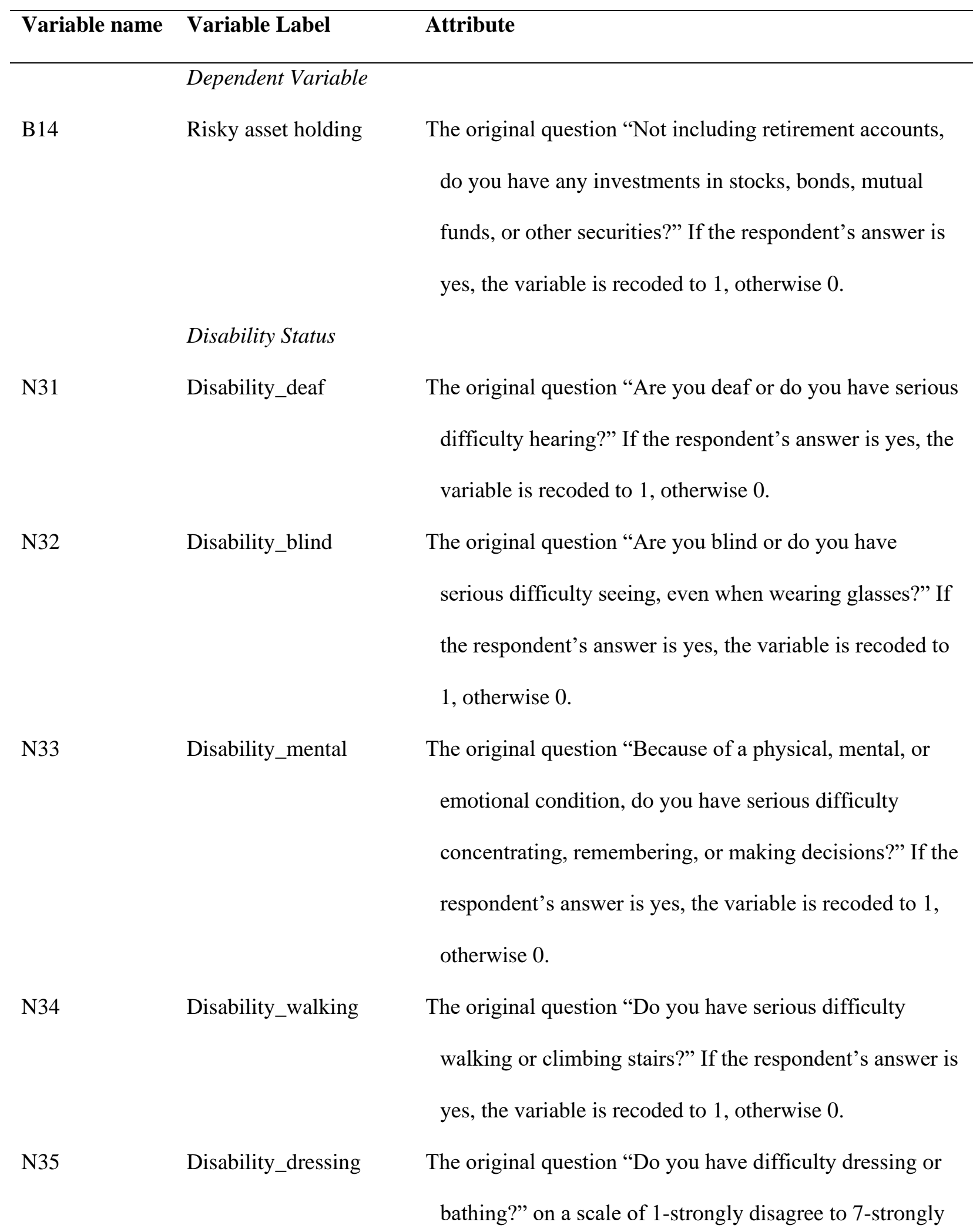


agree. If the respondent's answer is yes, the variable is recoded to 1 , otherwise 0 . emotional condition, do you have difficulty doing errands alone such as visiting a doctor's office or shopping?" If the respondent's answer is yes, the variable is recoded to 1, otherwise 0 .

The original question "Which of the following best describes your current employment or work status?" If the respondent's answer is "Permanently sick, disabled, or unable to work ... 6," the variable is recoded to 1 , otherwise 0 .

\section{Financial Capability} questions. The original financial literacy variables (m6m10) were recoded to binary variables in which $1=$ correct answer, $0=$ otherwise and then the new variables were summed to form the score. These questions asked financial knowledge about interest (m6), inflation (m7), bond (m8), time value of money (m31), mortgage (m9), and stock (m10). More details about these questions can be found at Lin et al. (2016).

M1_1

Subjective knowledge 1-very low, 7-very high. which is ranged 0-5. These variables are appropriately 
recoded from corresponding variables in the original data set: j3 (underspend), , j5 (emergency fund), j31 (budget), j33_3(long term planning), and j8j9 (calculate retirement need).

J1

$\mathrm{J} 2$

A3a

A3

A6

A11

A5

A5

A5

J20

F1

F2_2

Ea_1

A8

A8

A8

C3

C4

A9
Financial capability

\section{Other Variables}

Risk attitude

Age

Male

Married

Have children

High school or lower

Some college

Associate or higher

No $\$ 2000$

No credit card

Have credit card debt

Own home

Income, under $\$ 25 \mathrm{k}$

Income, $\$ 25 \mathrm{k}-\$ 50 \mathrm{k}$

Income, $\$ 50 \mathrm{k}$ or highe

Have $401 \mathrm{k}$ etc.

Have IRA etc.

Working
1 means 'Not At All Willing' and 10 means 'Very Willing."

Actual year of age

Recoded, $1=$ male, $0=$ female

Recoded, $1=$ married, $0=$ not married

Recoded, $1=$ yes, $0=$ no

If high school graduated or lower, $1=y e s, 0=$ no.

If some college, $1=$ yes, $0=$ no.

If associate degree or higher, $1=y e s, 0=$ no.

$1=$ yes, $0=$ no.

If "no credit cards - 7", 1=yes, $0=$ no

$1=$ yes, $0=$ no

Recoded, 1=yes, $0=$ no

If income under $\$ 25 \mathrm{k}, 1=$ yes, $0=$ no

If income $\$ 25 \mathrm{k}$ but under $\$ 50 \mathrm{k}, 1=\mathrm{yes}, 0=\mathrm{no}$

If income $\$ 50 \mathrm{k}$ or higher, $1=$ yes, $0=$ no

$1=$ yes, $0=$ no

$1=$ yes, $0=$ no

$1=$ yes, $0=$ no

Note: Variable names are from the codebook of the 2015 NFCS. 
DISABILITY TYPE AND RISKY ASSET HOLDING

Table 2. Descriptive Statistics of the Sample $(\mathrm{N}=4,920)$

\begin{tabular}{|c|c|c|c|c|c|c|}
\hline Variable & Total & & Income & Under $\$ 75 \mathrm{k}$ & Income & $\$ 75 \mathrm{k}$ or more \\
\hline & Mean & SD & Mean & SD & Mean & SD \\
\hline Risky asset holding & 0.19 & 0.39 & 0.13 & 0.34 & 0.49 & 0.50 \\
\hline Disability_deaf & 0.18 & 0.39 & 0.15 & 0.36 & 0.35 & 0.48 \\
\hline Disability_blind & 0.15 & 0.36 & 0.14 & 0.34 & 0.21 & 0.40 \\
\hline Disability_mental & 0.46 & 0.50 & 0.48 & 0.50 & 0.38 & 0.49 \\
\hline Disability_walking & 0.46 & 0.50 & 0.46 & 0.50 & 0.42 & 0.49 \\
\hline Disability_dressing & 0.15 & 0.35 & 0.15 & 0.35 & 0.15 & 0.36 \\
\hline Disability_errand & 0.34 & 0.47 & 0.36 & 0.48 & 0.27 & 0.44 \\
\hline Disability_work & 0.24 & 0.43 & 0.28 & 0.45 & 0.07 & 0.25 \\
\hline Objective know. (0-6) & 2.76 & 1.58 & 2.65 & 1.55 & 3.38 & 1.58 \\
\hline Subjective know. (1-7) & 4.91 & 1.41 & 4.80 & 1.43 & 5.49 & 1.15 \\
\hline Financial behavior (0-5) & 2.37 & 1.40 & 2.20 & 1.33 & 3.23 & 1.45 \\
\hline Fin. capability (1-7) & 5.38 & 1.64 & 5.31 & 1.66 & 5.79 & 1.44 \\
\hline Risk attitude (1-10) & 4.69 & 2.79 & 4.42 & 2.74 & 6.11 & 2.60 \\
\hline Age (18-65) & 44.08 & 14.26 & 43.82 & 14.39 & 45.50 & 13.41 \\
\hline Male & 0.43 & 0.49 & 0.40 & 0.49 & 0.54 & 0.50 \\
\hline Married & 0.42 & 0.49 & 0.36 & 0.48 & 0.75 & 0.43 \\
\hline Have children & 0.36 & 0.48 & 0.33 & 0.47 & 0.51 & 0.50 \\
\hline High school or lower & 0.35 & 0.48 & 0.38 & 0.48 & 0.18 & 0.38 \\
\hline Some college & 0.32 & 0.47 & 0.33 & 0.47 & 0.23 & 0.42 \\
\hline Associate degree or higher & 0.33 & 0.47 & 0.29 & 0.45 & 0.59 & 0.49 \\
\hline
\end{tabular}


DISABILITY TYPE AND RISKY ASSET HOLDING

\begin{tabular}{lcccccc} 
No \$2000 & 0.54 & 0.50 & 0.60 & 0.49 & 0.21 & 0.41 \\
No credit card & 0.35 & 0.48 & 0.40 & 0.49 & 0.08 & 0.27 \\
Have credit card debt & 0.36 & 0.48 & 0.34 & 0.47 & 0.45 & 0.50 \\
Own home & 0.48 & 0.50 & 0.42 & 0.49 & 0.79 & 0.41 \\
Income, under \$25k & 0.42 & 0.49 & & & & \\
Income, \$25k-\$50k & 0.27 & 0.44 & & & & \\
Income, \$50k or higher & 0.31 & 0.46 & & & & \\
Have 401k etc. & 0.22 & 0.42 & 0.16 & 0.37 & 0.56 & 0.50 \\
Have IRA etc. & 0.19 & 0.39 & 0.13 & 0.34 & 0.51 & 0.50 \\
Working & 0.39 & 0.49 & 0.34 & 0.47 & 0.64 & 0.48 \\
\hline
\end{tabular}


DISABILITY TYPE AND RISKY ASSET HOLDING

Table 3. Risky Asset Holding and Financial Capability by Disability Status

\begin{tabular}{lccccccccc}
\hline \multirow{2}{*}{ Variable } & & \multicolumn{3}{c}{ Disability } & Status & & & \multicolumn{2}{c}{ Total } \\
& Deaf & Blind & Mental & Walking & Dressing & Errand & Work \\
\hline Risky asset holding & 0.35 & 0.27 & 0.17 & 0.18 & 0.24 & 0.18 & 0.06 & 0.19 \\
Objective knowledge & 2.92 & 2.62 & 2.60 & 2.84 & 2.69 & 2.64 & 2.60 & 2.76 \\
Subjective knowledge & 5.26 & 5.13 & 4.68 & 5.02 & 5.10 & 4.88 & 4.74 & 4.91 \\
Financial behavior & 2.87 & 2.63 & 2.23 & 2.36 & 2.49 & 2.30 & 1.97 & 2.37 \\
Financial capability & 5.60 & 5.34 & 5.03 & 5.54 & 5.38 & 5.25 & 5.43 & 5.38 \\
\end{tabular}


DISABILITY TYPE AND RISKY ASSET HOLDING

Table 4. Logistic Regression Results on Risky Asset Holding (Odds Ratios) for the Full

Sample and Income Subsamples

(1)

(2)

Full Sample Income under $\$ 75 \mathrm{k}$ Income $\$ 75 \mathrm{k}$ or more

\begin{tabular}{|c|c|c|c|c|c|c|}
\hline Disability_deaf & 1.354 & $* *$ & 1.487 & $* *$ & 1.139 & \\
\hline Disability_blind & 1.022 & & 1.113 & & 0.809 & \\
\hline Disability_walking & 1.091 & & 1.112 & & 1.068 & \\
\hline Disability_dressing & 1.148 & & 1.170 & & 1.120 & \\
\hline Disability_errand & 1.454 & $* * *$ & 1.448 & $* *$ & 1.477 & \\
\hline Disability_work & 0.525 & $* * *$ & 0.481 & $* * *$ & 0.693 & \\
\hline Objective knowledge & 1.136 & $* * *$ & 1.146 & $* * *$ & 1.103 & \\
\hline Subjective knowledge & 0.997 & & 1.002 & & 0.961 & \\
\hline Financial behavior & 1.218 & $* * *$ & 1.185 & $* * *$ & 1.333 & $* * *$ \\
\hline Financial capability & 1.005 & & 1.021 & & 0.974 & \\
\hline Risk attitude & 1.151 & $* * *$ & 1.132 & $* * *$ & 1.237 & $* * *$ \\
\hline Age & 0.931 & $* *$ & 0.948 & & 0.888 & $*$ \\
\hline Age squared & 1.001 & $*$ & 1.000 & & 1.001 & $*$ \\
\hline Male & 1.010 & & 1.101 & & 0.691 & \\
\hline Married & 0.836 & & 0.970 & & 0.627 & \\
\hline Have children & 0.891 & & 0.827 & & 1.209 & \\
\hline Some college & 0.958 & & 0.912 & & 1.240 & \\
\hline Associate or higher & 1.232 & & 1.353 & $*$ & 1.099 & \\
\hline No $\$ 2000$ & 0.615 & $* * *$ & 0.611 & $* * *$ & 0.487 & $* *$ \\
\hline
\end{tabular}


DISABILITY TYPE AND RISKY ASSET HOLDING

\begin{tabular}{|c|c|c|c|c|c|c|}
\hline No credit card & 0.423 & $* * *$ & 0.411 & $* * *$ & 0.434 & \\
\hline Have credit card debt & 0.800 & $*$ & 0.863 & & 0.682 & $*$ \\
\hline Own home & 1.875 & $* * *$ & 1.961 & $* * *$ & 2.087 & $* *$ \\
\hline Income, $\$ 25 \mathrm{k}-\$ 50 \mathrm{k}$ & 1.208 & & & & & \\
\hline Income, $\$ 50 \mathrm{k}$ or higher & 1.816 & $* * *$ & & & & \\
\hline Have $401 \mathrm{k}$ etc. & 1.433 & $* * *$ & 1.516 & $* * *$ & 1.394 & \\
\hline Have IRA etc. & 4.310 & $* * *$ & 4.307 & $* * *$ & 4.318 & $* * *$ \\
\hline Working & 1.083 & & 1.053 & & 1.410 & \\
\hline-2 log likelihood & 3032.028 & & 2266.587 & & 752.942 & \\
\hline Cox \& Snell $\mathrm{R}^{2}$ & .296 & & .211 & & .334 & \\
\hline Neglkerke $\mathrm{R}^{2}$ & .477 & & .389 & & .445 & \\
\hline
\end{tabular}

Note: reference categories: disability_mental, high school or lower, income under $\$ 25 \mathrm{k}$.

$* \mathrm{p}<.05 . * * \mathrm{p}<.01 . * * * \mathrm{p}<.001$. 
DISABILITY TYPE AND RISKY ASSET HOLDING

Figure 1

Risky Asset Holding by Income Among Adults with Disabilities

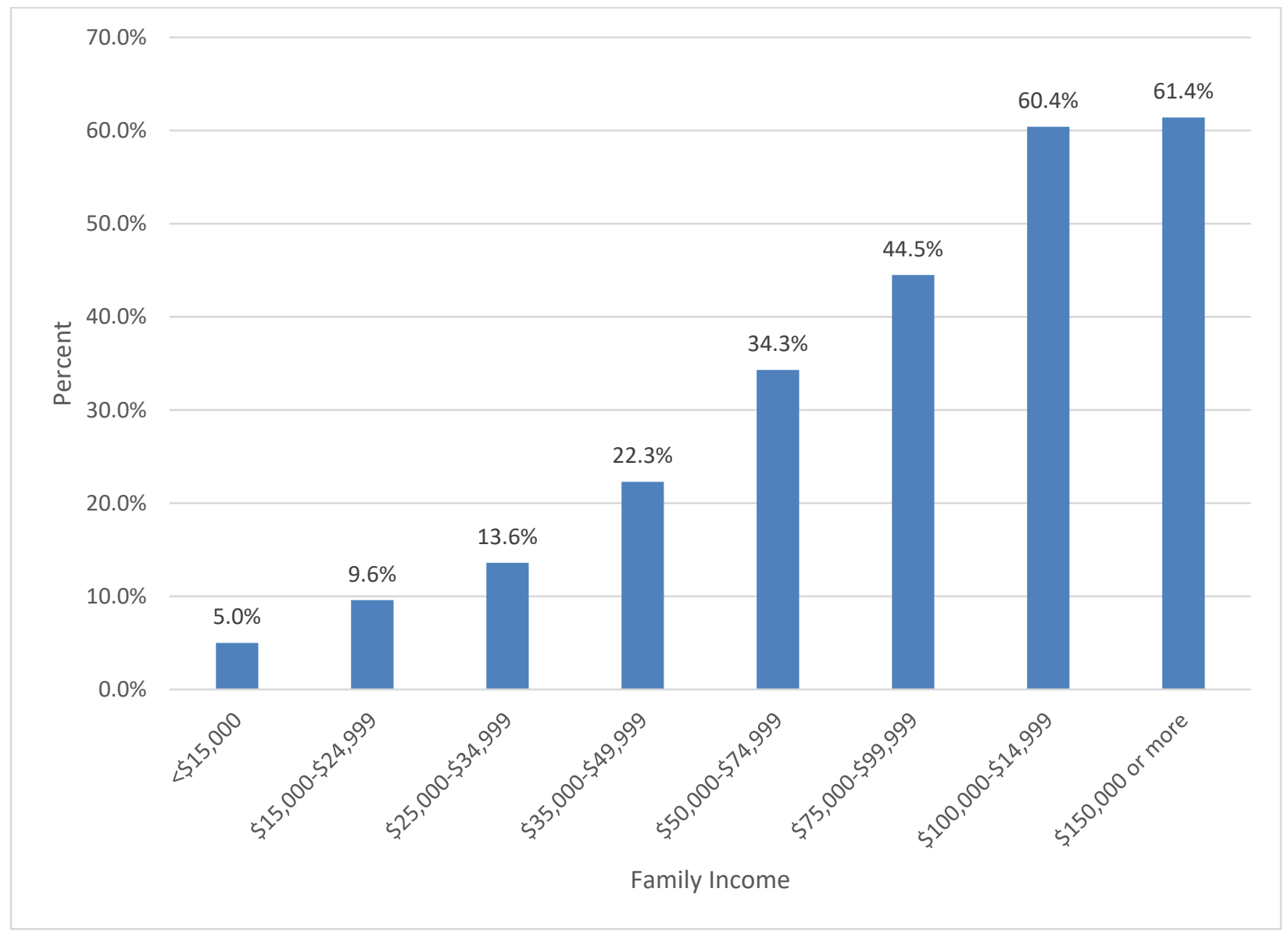

Note. Author calculation with data from the 2015 NFCS. 